\title{
Theatre in Algeria: Between Multilingualism, Interculturality and Transmission
}

\author{
Lilia Makhloufi
}

\begin{abstract}
In Algeria, theatre has evolved in response to different theories and practices, some related to political or spiritual ideologies, others based on cultural or artistic concerns. Some theatre processes focus on a story, some on an event, and others act as catalysts for social change.

This paper arises from an academic research project concerning ambiances in Algeria. It examines theatre in Algeria and its processes of transmission, at the same time, linguistic, socio-political, cultural, artistic and educational, but particularly the transmission of identity, while analyzing the existing settings of reference and their effects on Algerian society and young people in particular.
\end{abstract}

Keywords - ambiances, culture, festival, theatre, transmission.

\section{INTRODUCTION}

In Algeria, theatre is the expression of the culture that built the country, a heritage that proves to be complex. Today, in a period of globalization, Algerian culture appears either as a product that can be sold within tourist industries, or as a base for genuine identities that has to be preserved. Globalization implies often the extension of an activity, a technique or a language on a world scale, and also a multiplication of international interdependences. According to Jean-François Dortier, the West had colonized the world previously by strength, producing thus ethnocide. Today, westernization develops mainly by acculturation, a voluntary adherence [1].

Therefore, how to protect Algerian culture when this one is vulnerable by the acculturation generated by the phenomenal development of technological means? Would theatre help to preserve social ties and collective memories? And besides, does Algerian theatre call for a specific place? Or better yet a specific public?

Algeria is a Muslim country since the Arab conquest in the 7th century. The dominant European influence is the one of France that colonized Algeria in 1830. It has not been easy for theatre to flourish in Algeria. The Arab-Muslim tradition gave it little encouragement. French censorship was always ready to suppress any criticism of the colonial authority. Therefore, theatre tented to come largely from outside the country. In the 19th century, shadow theatre from Turkey was popular.

Theatre companies from Egypt visited time to time. Touring French theatre companies provided entertainment mainly for

Lilia Makhloufi is with the Ecole Polytechnique d'Architecture et d'Urbanisme (EPAU) Algiers, Algeria
French citizens living in Algeria and the French-speaking Arab elite, their performances were almost inspired from the Parisian Boulevard theatres.

After the Liberation War and the Independence of Algeria [July 51962], all kinds of theatrical activity increased. The National Theatre in Algiers (TNA) has been established in 1963. Algeria, Morocco and Tunisia were well represented in the drama section of the Pan-African Festival (FESTAC) held in Algiers in 1969. However, theatre has been hampered by the language used in literary production, a classical Arabic that makes plays difficult to understand by ordinary people.

In fact, Algerian people appreciated more the work of Rachid Ksentini who wrote and directed many successful plays in spoken Arabic. Directors and playwrights committed to the nationalist movement realized the importance of Ksentini's work in the future development of people's theatre in independent Algeria. His ideas were approved by Mahieddine Bachtarzi and Mustapha Kateb in particular, respectively director of the Municipal Conservatoire of Algiers and director of the National Theatre (TNA) in Algiers.

Another remarkable work is the one of Kateb Yacine. According to Stanton and Banham, the French-speaking Algerian playwright and novelist Kateb Yacine is well known in France for his realistic and frank attacks on French colonialism in North Africa. His plays have been directed by Jean-Marie Serreau. Yacine's often violent language and style are as much those of the poet as of the dramatist, and his theatre, like his novels, offers a vision of human behavior which is far more nuanced than the simple portraits of political theatre [2].

Nowadays, theatre remains a fundamental element for the preservation of Algerian identity, because that one does want it or not, identities construct themselves, even today, essentially in a territorialized dimension. Theatre contributes largely to the development of a positive image of Algeria by emphasizing its multilingualism and its pluriculturality, and by enhancing the cultural capital of the population (Berbers in particular).

\section{The Algerian Theatre As A TRANSMission SOURCE OF IDENTITY}

Algerian theatre is not the work of the present generation nor of the previous, it is the persistent and continuous work of several generations. However, there are many factors that hindered the development of theatre despite its dramatic, 
artistic, symbolic and linguistic components. Actually, during the nineties, there was a security crisis in Algeria. As reported by the journalist Kamel Bendimered from the Algeria Press Service, the big names of the Algerian stage disappeared (because of natural or violent death, exile, political erasure) such - for the last half-century - Boualem Raïs, Rouiched, Ould Abderrahmane Kaki, Kateb Yacine, Abdelkader Alloula, Slimane Benaïssa and M'hamed Benguettaf, supported for most of them by voluntarist actors and producers of beautiful lineage (Allel El Mouhib, Hadj Omar, Hachemi Noureddine, Sid Ahmed Agoumi, Malek Bouguermouh, Ziani-Cherif Ayad, Azzeddine Medjoubi...) [3]. This critical situation emphasises the challenge to replace these renown playwrights, directors and actors.

Today, some theatre critics say that Algerian theatre suffers from an excessive bureaucratic management, a lack of artistic and technical background, a lack of professionalism as regards public relations, and a cruel absence of a cultural policy that makes difficult the replacement of playwrights, directors and actors who sacrificed themselves in order to make known the tragedy of Algeria during the French colonialism like Mustapha Kateb, Boualem Rais, Kateb Yacine, Henri Kréa, Hocine Bouzaher and Mohamed Boudia, from where the necessity to examine theatrical buildings and other spaces dedicated to practitioners.

The National Theatre (TNA) is actually the former Opera of Algiers. This masterpiece of nineteenth-century architecture [built 1843-1853] is the work of the French architect Chasseriau, with a surface of $8467 \mathrm{~m}^{2}$ for 750 spectators. The former Opera of Constantine and of Oran are considered as two major regional theatres situated respectively in the east and west side of the country. There are also regional theatres in many cities like Annaba, Bejaïa and Batna. All these theatre were built during the colonial period, and needed many operations of restoration which have been undertaken by the local authorities.

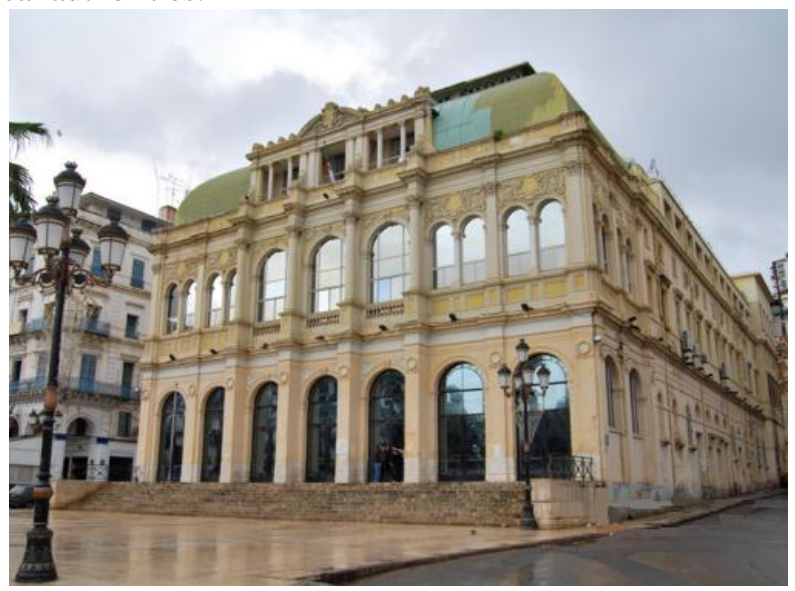

Fig. 1: the National Theatre (TNA) in Algiers Photograph courtesy of Lilia Makhloufi

In Algeria, theatre is considered as a 'national public service' and professionals use the stages with the material means put at their disposal, while receiving monthly salaries[4]. But the lack of production is obvious, with only one new play per year sometimes that doesn't arouse the interest of the audience besides. What about actors? Why are they rarely solicited?

For Algerian people, culture or cultures abound outside the workshops where one makes arts, outside the walls where one makes dramaturgy, and theatre is simply a passion that besides, should not be limited to performances inside theatre buildings. In fact, fundamental principle that authenticates all shape of arts, the audience has to be in accordance with the performers in order to understand the meaning of the play, in this sense, the dramatic language becomes an expressive artistic language highlighted with lighting effects, music, scenography and choreography, while emphasising the performance of the actors. According to Kamel Bendimered, when this language is not anymore thought in an objective of communication with its natural listeners, and gives the tensing impression to turn towards an 'amphitheatrical' style or a professorial 'demonstration', when theatrical experiences reach an impasse, it is imperative to pull the alarm bell [5].

Today, many plays are performed in an Arabic language for the least 'hermetic' rarely accessible to the understanding of the Algerian audience, and judged artificial by several practitioners of the stage. Let's underline that some theatre directors opted for the export of Arab plays. The target is not anymore the Algerian spectator who becomes secondary, but the promoters of Arab theatrical manifestations. Therefore, how to develop this modern language with the colors and the flavors of the Algerian country, in order to reach a dramaturgical enrichment and not uniformity? What about dialectal linguistic transmission, does it have an impact on Algerian theatre?

\section{A. The National Festival of Amazigh Theatre: a Linguistic Transmission at Stake}

The big names of the Algerian stage granted a major attention to the artistic language or the scenic language, having therefore the tendency to combine the vitality of the spoken language with the rigor of the written language. Let's mention for instance, the regretted Abdelkader Alloula who made a great illustration of this principle, and who is considered like a reference by Algerian people. During an interview granted to the Algeria Press Service in 1985, Alloula said:

I am not a specialist of the language and I don't have the intention to become one. I choose the words that can have an impact in the spectator's memory [...]. When one lends a deep ear to the popular dialogue, one realizes the existence of metaphors and rich, very rich pictures [6].

Therefore, the major preoccupation was to be in phase with the cultural and linguistic heritage of the Algerian population, privileging this way, an Arabic language more conversational. Certainly, the classical Arabic is the official language of the country; although in the current life, Algerians speak a dialectal Arabic, commonly called 'derdja' that differs from the classical Arabic by its morphology, its pronunciation and its vocabulary. But since April 2002, Tamazight (a Berber language spoken in the northeast of Algeria) has been 
recognized like national language [7].

Indeed, the nineties marked the awakening of the Kabyle people wanting to assert their language, their culture and their customs. The threshold of social uprisings has been reached in the beginning of the year 2000. The result was the recognition of 'Amazigh' language followed by its teaching in school establishments, and finally the development of this Berber language beyond its geographical boundaries.

In theatre, new plays in Kabyle language and others in Chaoui language (two variants of the Berber language used respectively in Kabylia and in the Aures Massif) emerged in different regions of the country. Indeed, the quick survey of three contrasting Algerian regions, the Kabylia, the Aures Massif and the M'zab Valley, emphasises the existence of many different identities and spatial references. Actually, integrating Algerian communities who live in these regions into the vast territory of Algeria, while safeguarding their way of life, culture and language, is more than ever indispensable. Would theatre become a federator of the preservation of Algerian culture?

A first national cultural festival of Amazigh theatre has been organized in December 2009 in the regional theatre of Batna city, the capital of the Aures Massif, in northeastern Algeria. This national festival instituted by the Ministry of Culture is opened to theatrical troupes of Amazigh expression, acting on a national scale in order to encourage the development of artistic creations and theatrical performances in Amazigh language, the ultimate objective being to promote the Berber culture.

This first edition emphasises also the emergence of Amazigh theatre, with special acknowledgments to three prominent figures from Kabylia, Aures Massif and M'zab Valley, respectively Saïd Hilmi (from Tizi-Ouzou city), Salim Souhali (from Batna city) and Ali Bouras (from Ghardaïa city), for their efforts to improve Algerian theatre in general and Amazigh theatre in particular. Since then, many Amazigh festivals have been organized; these events incited many troupes to increase their creativeness in order to perform quality plays in Amazigh language.

\section{The Algerian Amateur Theatre As A Socio- POLITICAL VECTOR OF TRANSMISSION}

One cannot speak about theatre in Algeria without evoking the first Algerian theatregoers, who attended some plays during their unprompted visits to theatres, theatres that were built for colonists at first place, and who were very inspired to perform their first 'sketches' in front of the oppressed Algerian people during the French colonialism. Since the independence of Algeria, these men of the stage or these 'youths' of the stage, seduced by the discovery of the Fourth Art, learned some elementary techniques of theatrical representations, reorganized themselves in small troupes and started to perform new plays.

Today, all over Algeria, many troupes emerge and give public performances outside theatre buildings, in different public places, restoring this way, the cultural vocation and the popular life. Public spaces become the favourite place for Algerian amateurs. These young people highlight an amateur theatre, perform all kind of social, economic and political problems, without any adequate material or consequent financial means, nevertheless their human wealth captivates the spectator. Would amateur theatre become the driving force behind the theatrical development in Algeria?

In order to understand the impact of amateur theatre on the transmission of linguistic, cultural and historical aspects, specific to Algeria, a diachronic survey is necessary. According to Ahmed Cheniki and Makhlouf Boukrouh, amateur theatre knew three successive and more or less distinct phases (1962-1970, 1970-1980 and 1981-1991) [8]. From our different readings on that subject, it emerges that:

The first phase, qualified as 'shy', is the one of the sixties, where amateur theatre themes and performances are inspired from the repertoire of the Algerian troupes before the independence and performing until the late 1960s. This phase has been dominated by plays in reference to the theatre of Ksentini, Allalou, Bachetarzi and Touri [9].

The second phase, the one of the seventies, is richer when it comes to artistic production and theatrical quality. This phase is characterized by two major political facts: the events of May 1968 in France, and the death of the Algerian President Boumediene in December 1978, a period of questioning concerning the different political actions led in France and in Algeria. However, this phase knew its apogee in 1970, thanks to the creation of the national festival of amateur theatre on the 1st of September 1969 in Mostaganem city.

This festival gave people of culture the opportunity to be on stage in order to stimulate the Algerian population, while evoking numerous social problems and while blending political and cultural contexts. It is in this effervescence that appeared besides, the best troupes of amateur theatre in Algeria. The third phase is, as for it, the one of the eighties and the nineties, a period characterized by several riots and security crisis in Algeria, that have negative repercussions on amateur theatre with a significant lack of production.

\section{A. The National Festival of Amateur Theatre: a Cultural Transmission at Stake}

Amateur theatre is a place of gathering for 'non professional' troupes since 1967. It takes place in Mostaganem city, in northwestern Algeria on the Mediterranean coast. At the beginning, these meetings were limited to troupes based in northwestern Algeria, but they pursue their development until the creation of the national festival of amateur theatre in Mostaganem city [September 1 1969], offering a national cultural event. The first editions were organized by the cultural commission of the Islamic Scouts, and included the performances of ten regional troupes. Today, this event is open to all kinds of amateurs with numerous theatrical representations.

Organized in Mostaganem city each summer, the national festival of amateur theatre celebrated its 50th edition in 2017 
inside the cultural centre of Ould Abderrahmane Kaki, in memory of this renowned stage performer. Usually, in MarchApril, a preselection takes place to choose the best theatrical troupes. As reported by the Algeria Press Service, theses editions planned several representations for children in the old places of Mostaganem city, seminaries and conferences about Algerian playwrights, directors and actors, with a marquee reserved to poetry, workshops and readings of theatrical texts for children.

In order to support this event, different theatrical representations for children and adults (out contest) were performed in cultural associations like the one of 'Ould Abderrahmane Kaki' in Mostaganem city, on the one hand. On the other hand, conferences concerning the pioneers of Algerian theatre are organized, such as Abdelhalim Rais, Kateb Yacine, Abdelkader Alloula and Ould Abderrahmane Kaki. Each September 1st, a 'nonstop theatre' is organized in order to celebrate worthily the anniversary of the creation of this national festival, with unstoppable plays for children and for adults, conferences and meetings on the history of Algerian theatre.

Another prominent contest is the price 'Kaki of gold'. The fifth and last edition took place on the 30th of August 2012 and rewarded the best theatrical texts. Young writers, novelists and other theatrical cooperatives were in competition to get one of the four Kaki prices: gold, silver and bronze prices as well as the one of the Jury estimated between 100.000 and 300.000 Algerian dinars.

Consequently, one cannot speak about theatre in Algeria, while ignoring the impact of amateur theatre. Nowadays, many ex-amateurs perform in 'public theatres'. This fact strengthens the effects of this human experience, result of a collective creation, shared by people wanting to develop Algerian scenic art. These amateurs, who didn't necessarily perform high standard artistic representation, knew how to transform theatre into a place of social and political intervention. They highlighted the socio-cultural aspects of the country and paid homage to the big names of the Algerian stage. Moreover, the numerous ceremonies and parades enhance the atmosphere of feast with which local people welcome these artistic events and this creates an ambiance that is linked to the restoration of local traditions and heritage.

\section{The Theatrical Ambiance As Approach To AN ARTISTIC TRANSMISSION}

Researchers have come to call 'ambiance' a global apprehension, immediate or corporally felt, of the space, and ambiances in the plural, sensorial and mediate modalities or apprehensions [10]. Because of their artistic, cultural and imaginary dimensions, and their effects on Algerian society and young people in particular, theatre spaces were a case study in our research project.

The term ambiance - often confined in literature to steamy, autumnal or festive atmospheres - imposed itself a few years ago as a relevant instrument for spatial analysis and design, and became a foundation for many theoretical and operational practices. This approach to the built environment involves all the senses (sound, light, odors, touch, heat, etcetera). In Algeria, cultural ambiances relate to a revival of interest in local values, and preserve the richness of local ways of life. The Algerian public value what is specific to Algerian culture, in contrast to global culture, or even pan-Arabic or panAfrican culture [11].

By their sensorial and emotional work, performers provoke the feelings of the spectators. Certainly, a play is not the work of an individual. Playwrights, directors, actors, scenographers, and musicians work all together in order to realize theatrical representations. The Algerian audience reacts in its own way to judge all these plays, their relevance, success or failure, strength and consistency.

If we reconsider the festival of Batna city and the one of Mostaganem city, we would see that these cultural events, demanding the audience's attention, are not temporary. These festivals require a huge organization that often spreads over several months, emphasise the moment when several troupes are in competition for the price, and continue beyond their closing ceremonies with all theatrical critics and other commentaries that will determine their relevance. If they are successful, this will guarantee that Algerians will be present next time, convinced that theatre is wonderful, they will not miss it.

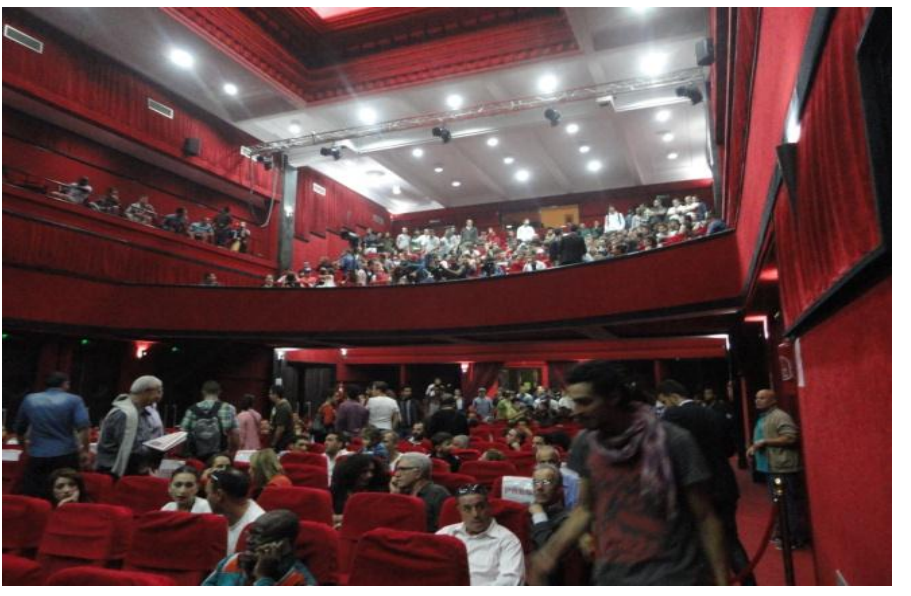

Fig. 2: The audience in the International Festival of the Theatre in Bejaïa city, Photograph courtesy of Lilia Makhloufi

\section{V.THEATRE For CHILDREN AS POTENTIAL FOR AN EDUCATIONAL TRANSMISSION}

In many regions, where the presence of theatre for children, commonly called 'theatre of the small world' is minimal or even absent, Algerian artists see festivals as being important, because performing for the 'young public' today will guarantee the attendance of an 'adult public' tomorrow. As Antoine de Saint-Exupéry writes in his novella The Little Prince: 'All grown-ups were once children... but only few of them remember it'.

Currently, there are theatrical days which take place during school holidays. Organized by almost every theatre and also by 
cultural centres, these events are well attended by children and their families. At the Theatre of Constantine city, in northeastern Algeria, we had the opportunity to interview schoolchildren aged between 6 and 10 years old during the theatrical days of December 2015, and this young audience reacted in a subjective and personal way.

In their own words, 'theatre is above all a building richly decorated with a main staircase made of marble'. Actually, the theatre building where they saw the play is the former Opera of Constantine. This masterpiece of nineteenth-century architecture [built 1861-1883] is the work of architects Gion and Monnier. The construction of the theatre is associated with painters and sculptors influenced by Italian style of Renaissance. The auditorium, with its paintings, motifs, sculptures, decor, columns, red seats and walls, recalls the Italian proscenium, and has a striking impact on a visitor. But for schoolchildren:

Theatre is magic when they turn off the light of the huge chandelier in the ceiling and use several colorful lighting effects ... We liked the music, it was pretty lively, we applauded a lot during the play ... We liked the moment when we were in the dark and suddenly actors had sprung from nowhere, they were really funny ...

Actually, the stage area becomes a complex space in which artistic ambiances take effect. The schoolchildren's feedback confirms that lighting effects (soft, colourful, dark with bright intervals, etcetera), and sound effects (artists voices, whispers, footsteps, musical instruments, noises off, etcetera), in addition to decors, costumes, scenography -all these ambient factors transform the stage, where performances take place - into a 'multi-sensorial' space that directly resonates in the children's imaginary. Conditioning the success of any theatrical representation, these factors should be disposed meticulously, with fineness and subtleness. In Algeria, more and more, as theatre artists try to improve their technical skills and artistic approaches, children are getting the opportunity to experience the stage as a set of intermingled elements that create ambiance [12].

Currently, a theatre for 'young public' has been launched, but its influence on children and their relation to arts and cultural activities needs to be enhanced. Indeed, beyond the fact that Algerians see theatre as primarily a didactic instrument, children do not learn theatre at schools. In Algeria, the smallest (5-10 years old) do some acting at primary schools to celebrate either the end of the school year or some local feasts, whereas the eldest (11-14 years old) do some performances during competitions between secondary schools. However, true learning only happens if there is a training process and a follow-up.

Currently, Algerian schoolchildren participate to theatrical activities, but they do so without a clear artistic objective. At school, they enliven characters during theatrical representations by drawing on the strength of their imaginations, but they do not attach importance to the bodily expression, and their performances become a simple reproduction of stereotyped gestures, or a recitation of texts and literatures while using costumes. A real pedagogical transition is necessary to free them to act spontaneously and to improvise when they perform.

However, it seems that theatre for children in Algeria is finally recognised as an art and a valuable cultural product. The recent children's theatre festival, produced by the Ministry of Culture in Khenchela city in northeastern Algeria since 2008, includes gorgeous masks made of gold, silver, and bronze as prizes for the best performances. The fact that opening ceremonies coincided with June 16, the Day of the African Child, inspired huge colourful parades featuring thousands of children waving pictures and promoting cultural and educational messages.

Moreover, many cultural ambiances happen on April 16, commonly called 'The Day of Knowledge' in Algeria. Dedicated to learning while having fun, this day was celebrated first in Constantine to pay homage to Abdelhamid Ibn Badis (the Founder of the Association of Muslim Scholars), then extended to the whole country. In order to create an atmosphere of feast in each region, many theatres produce plays and encourage adults to bring their children. Constantine city centre emphasises its cultural life through its theatre and surrounding public spaces. Cultural activities produced in the main streets and places create urban ambiances and as a result culture has become a privileged means of affirming local identity.

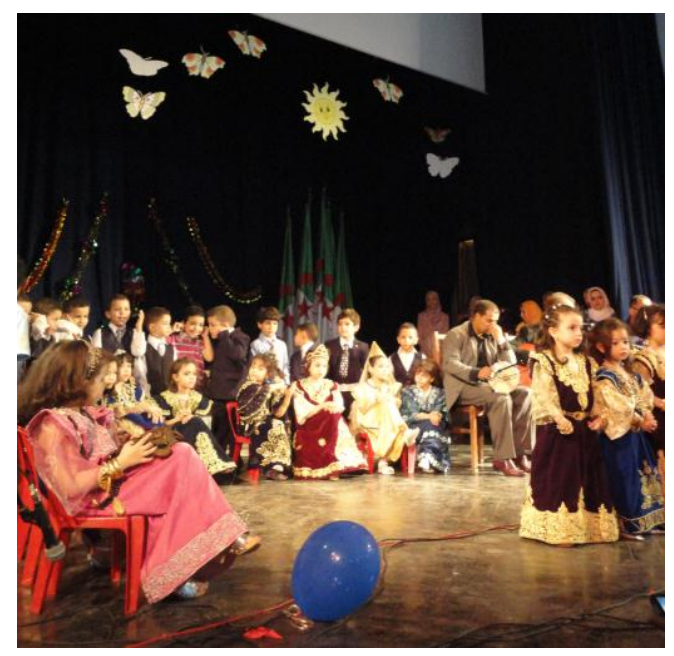

Fig. 3: Children on the stage in the theatre of Constantine Photograph courtesy of Lilia Makhloufi

\section{CONCLUSION}

According to Terrain Adair-Lynch, 'Theatre requires an audience. For all of the arts public is essential. The physical presence of an audience can change a performance, inspire actors, and create expectations. Theatre is a living breathing art form. The presence of live actors on the stage in front of live audiences sets it apart from modern day films and television' [13].

In Algeria, theatre deserves to be strongly encouraged by academics and practitioners. For the future as well as for the 
present, for the benefit of local authorities, cultural structures, and the school system, it is imperative that theatre be embedded in the Algerian cultural universe. The best way is to introduce it as part of the culture of children at a very young age. Theatre work needs adequate government support, and artists need theatre training (writing, voice, bodily expression, etcetera). Public authorities should instigate all kinds of theatrical initiatives, when increasing the numbers of festivals and conferences on theatre. These need more administrative, policy, and financial support.

Let's join Taha Lamiri, member of the artistic troupe of the National Front of Liberation (created in 1958) and old director of the National Theatre (TNA) in Algiers, to say that some people go astray and don't understand that theatre is above all a pleasure and not an unpleasant task that one imposes to the spectators. The big names of any artistic discipline never forget who made them kings [14].

\section{REFERENCES}

[1] J.-F. Dortier, "Vers une uniformisation culturelle?", in Sciences Humaines, vol.180, March. 2007. Accessed April 12, 2007. http://www.scienceshumaines.com/10-questions-sur-lamondialisation_fr_279.htm

[2] S. Stanton, and M. Banham. The Cambridge Paperback Guide to Theatre. Cambridge University Press, 1996, p.7

[3] K. Bendimered, "Le langage et la culture populaire sont exclus des planches. Le théâtre algérien est-il en brouille avec son identité ? ", in the national daily La Tribune, January 1, 2013. Accessed April 10, 2013. http://www.latribune-online.com/culture/76849.html

[4] Decree $\mathrm{n}^{\circ}$ 63-12 of January 8, 1963 concerning the organization of the Algerian theatre. Creation of a national troupe called National Theatre (T.N.A.). Creation of a national centre for Algerian theatre, (C.N. T. A.).

[5] K. Bendimered, "Le langage et la culture populaire sont exclus des planches. Le théâtre algérien est-il en brouille avec son identité ? ", in the national daily La Tribune, January 1, 2013. Accessed April 10, 2013. http://www.latribune-online.com/culture/76849.html

[6] op. cit.

[7] Law $n^{\circ}$ 02-03 dating from Moharram 27, 1423 corresponding to April 10, 2002 concerning constitutional revision. "Article. 3 bis - Tamazight is also national language. The State works at its promotion and at its development in all its linguistic variety in use on a territorial scale".

[8] A. Cheniki, and M. Boukrouh, "Le théâtre en Algérie, état des lieux et propositions de sortie de crise", in le blog de l'Action Culturelle Algérienne. Articles: réflexions/travaux, May 2008. Accessed April 10, 2013.http://s3.archivehost.com/membres/up/1890583760/LetheatreenAl gerieetatdeslieuxetpropositionsdesortiedecrise.pdf

[9] op.cit, p.20.

[10] H. Torgue, "Pour une convergence des expertises. L'ambiance au croisement du vécu, de la recherche et de l'art", in Ambiances in action/Ambiances en acte(s), J.-P Thibaud and D. Siret Ed., Montreal : Ambiances International Network, 2012, p.41.

[11] L. Makhloufi in dialogue with H. Fitzsimmons Frey. "Theatre in Algeria and Children - A dialogue on history, culture and ambiances", in Research in Drama Education (RIDE): The Journal of Applied Theatre and Performance, London: Routledge, Taylor \& Francis Group, vol. 21 $\mathrm{n}^{\circ}$. 4, 2016, pp.10-11

[12] op.cit, pp.13-14.

[13] T. Adair-Lynch. History of the World Theatre. Theatre Arts 5 lecture one: Elements of Theatre and Drama, 2012. Accessed November 1, 2015. homepage.smc.edu/adair-lynch_terrin/ta\%205/elements.htm

[14] K. Bendimered, "Le langage et la culture populaire sont exclus des planches. Le théâtre algérien est-il en brouille avec son identité ? ", in the national daily La Tribune, January 1, 2013. Accessed April 10, 2013. http://www.latribune-online.com/culture/76849.html
About Author :

Lilia Makhloufi is an architect, teacher and researcher at the School of Architecture (EPAU) in Algiers. Fond of theatre since her very young age, Lilia decided to emphasise theatre in Algeria in her research project. Since then, she has taken part in conferences in Algeria and abroad, and published an article on Algerian theatre in a book at Bordeaux University Press in France. Her last article on Theatre in Algeria and Children - A dialogue on history, culture and ambiances, was published in 2016, in the journal Research in Drama Education (RIDE): The Journal of Applied Theatre and Performance, volume $21 \mathrm{n}^{\circ}$. 4, London: Routledge, Taylor \& Francis Group. 